K A N D A I

\begin{tabular}{|l|l|l|}
\hline Volume 17 & No. 1, Mei 2021 & Halaman 119-134 \\
\hline
\end{tabular}

\title{
KEPRIBADIAN TOKOH UTAMA DALAM NOVEL TANAH SURGA MERAH KARYA ARAFAT NUR \\ (Personality Of The Main Characters In Novel Tanah Surga Merah By Arafat Nur)
}

\author{
Dara Windiyarti \\ Balai Bahasa Jawa Timur \\ Jalan Siwalanpanji, Buduran, Sidoajo, Indonesia \\ Pos-el: darawindiyarti3@gmail.com
}

(Diterima: 22 Februari 2020; Direvisi: 8 Juni 2020; Disetujui: 19 April 2021)

\begin{abstract}
This study aims to describe the personality of the main character in novel Tanah Surga Merah by Arafat Nur. The theory used in this research is the psychoanalytic paradigm, especially Harry Stack Sullivan's interpersonal psychiatry. Data collection was carried out using library techniques. The method used for data analysis is descriptive analysis. From the analysis, it is known that the main character in the novel Tanah Surga Merah is a young man who has a concern to defend the Acehnese who have experienced violence from the Indonesian army in Nangroe Aceh Darussalam (NAD), so he decided to join the GAM army. The resistance of the main character to certain groups that commit violence against the people of Aceh, led him to become a fugitive who had to flee. The love of the main character for his hometown made him have to experience painful treatment by the authorities. The main character's efforts to protect himself, obtain miracles that lead him to achieve the joy of life. Thus, it can be concluded that the main character in the novel Tanah Surga Merah has a dynamic personality, namely positive personification, negative personification, and complex and realistic personification so that he has succeeded in achieving life's happiness.
\end{abstract}

Keywords: novels, main characters, personalities, literary psychology

\begin{abstract}
Abstrak
Penelitian ini bertujuan untuk mendeskripsikan kepribadian tokoh utama dalam novel Tanah Surga Merah karya Arafat Nur. Teori yang digunakan dalam penelitian ini adalah paradigma psikoanalisis, khususnya psikiatri interpersonal oleh Harry Stack Sullivan. Pengumpulan data dilakukan dengan teknik kepustakaan. Metode yang digunakan untuk analisis data adalah deskriptif analisis. Dari hasil analisis, diketahui bahwa tokoh utama dalam novel Tanah Surga Merah ditampilkan sebagai pemuda yang memiliki kepedulian untuk membela masyarakat Aceh yang mendapat kekerasan dari tentara Indonesia di di Nangroe Aceh Darussalam (NAD) sehingga ia memutuskan bergabung dengan tentara GAM. Perlawanan tokoh utama kepada kelompok tertentu yang melakukan kekerasan terhadap masyarakat Aceh mengantarkannya menjadi buron. Kecintaan tokoh utama terhadap kampung halamannya membuatnya harus mengalami perlakuan yang menyakitkan dari penguasa. Usaha tokoh utama untuk melindungi diri, mempertemukannya dengan keajaibankeajaiban yang mengantarkan dirinya meraih kebahagiaan hidup. Dengan demikian, disimpulkan bahwa tokoh utama dalam novel Tanah Surga Merah memiliki kepribadian yang dinamis yakni personifikasi positif, personifikasi negatif, dan personifikasi yang kompleks dan realistik sehingga mengantarkan dirinya berhasil meraih kebahagiaan hidup.
\end{abstract}

Kata-kata kunci: novel, tokoh utama, kepribadian, psikologi sastra

DOI: 10.26499/jk.v17i1.2207

How to cite: Windiyarti, D. (2021). Kepribadian tokoh utama dalam novel Tanah Surga Merah karya Arafat Nur. Kandai, 17(1), 119-134 (DOI: 10.26499/jk.v17i1.2207) 


\section{PENDAHULUAN}

Rentetan aksi kekerasan bersenjata oleh mantan tentara Gerakan Aceh Merdeka (GAM) menjadi salah satu persoalan yang hingga kini masih menghantui perdamaian di Aceh. Banyak hal yang melatarbelakangi terjadinya aksi kekerasan tersebut. Setelah terjadi kesepakatan damai, mantan elite tentara GAM membentuk partai politik lokal Aceh. Hal ini mengantarkan mereka terjun ke dunia politik praktis yang mengecewakan. Mereka dianggap telah mengkhianati idealisme perjuangan GAM. Mereka banyak "bermain" dalam relasi kroni politik dan berebut proyek di Aceh untuk mencari keuntungan. Rasa kecewa terhadap perilaku buruk mantan tentara GAM tersebut menimbulkan aksi kekerasan sebagian mantan tentara GAM lainnya. Konflik kedua kelompok mantan tentara GAM ini dimenangkan kelompok yang berkuasa, sedangkan kelompok yang lemah harus terusir ke luar Aceh dan menjadi buron. Bagi mantan penjuang yang hidup di pengasingan sebagai buron, tentu tidak mudah. Perasaan kecewa, marah, takut, dan tidak berdaya, selalu muncul dalam dirinya. Realitas kehidupan masyarakat Aceh setelah perjanjian damai yang gagal tersebut, diangkat oleh Arafat Nur dalam novel Tanah Surga Merah. Dengan penggambaran tokoh utama yang berani melawan kekuasaan politik lokal, novel ini menarik untuk dibaca dan dipahami.

Karya sastra dipandang sebagai pengungkapan dari apa yang telah direnungkan dan dirasakan orang mengenai segi kehidupan yang paling menarik minat secara langsung dan kuat sehingga pada hakikatnya, karya sastra adalah suatu pengungkapan kehidupan lewat bentuk bahasa (Hudson, 1961).
Karya sastra, khususnya novel, diciptakan oleh pengarang dengan tujuan untuk dinikmati, dipahami, dan dimanfaatkan tanpa melupakan bahwa sastra sebenarnya merupakan bagian pengungkapan masalah hidup, filsafat, dan ilmu jiwa (Darma, 1983).

Bertolak dari pendapat tersebut, unsur-unsur psikologi dalam karya sastra sebagai manifestasi kejiwaan para tokoh fiksional dalam kisahan perlu dipahami. Psikologi sastra adalah cabang ilmu sastra yang mendekati karya sastra dari sudut psikologi. Perhatian dapat diarahkan kepada pengarang, pembaca, atau teks sastra (Hartono \& Rahmanto, 1986).

Istilah psikologi sastra mempunyai empat kemungkinan pengertian, yakni (1) studi psikologi pengarang sebagai tipe atau pribadi, (2) studi proses kreatif, (3) studi tipe dan hukum-hukum psikologi yang diterapkan pada karya sastra, dan (4) mempelajari dampak sastra pada pembaca (Wellek \& Warren, 1989). Dari empat pengertian tersebut, pengertian ketiga paling berkaitan dengan bidang sastra.

Tujuan psikologi sastra adalah memahami aspek-aspek kejiwaan yang terkandung dalam suatu karya (Ratna, 2004). Psikologi sastra adalah sebuah interdisiplin antara psikologi dan sastra. Mempelajari psikologi sastra sama halnya mempelajari manusia dari sisi jiwa (Endraswara, 2008). Namun, dalam analisis psikologi sastra, tidak terlepas dengan kebutuhan-kebutuhan masyarakat.

Karya fiksi psikologis merupakan suatu istilah yang digunakan untuk menjelaskan suatu novel yang bergumul dengan spiritual, emosional, dan mental. Para tokohnya lebih banyak mengkaji emosional dan mental daripada mengkaji alur atau peristiwa (Minderop, 2011). Bertolak dari pendapat tersebut, kajian 
dari aspek mental dan emosional tokohtokoh dalam karya sastra sangat menarik karena dari sinilah dapat dipahami seberapa besar kekuatan manusia (tokoh) ketika menghadapi persoalan. Di samping itu, kita dapat belajar banyak dalam kehidupan realitas untuk mewaspadai diri sendiri atau diri orang lain ketika mendapat persoalan yang dapat menyerang batin (jiwa) kita.

Orang dapat mengamati tingkah laku tokoh-tokoh dalam sebuah roman atau drama dengan memanfaatkan ilmu psikologi. Andai kata tingkah laku tokoh-tokoh itu sesuai dengan apa yang diketahuinya tentang jiwa manusia, dia telah berhasil menggunakan teori-teori psikologi modern untuk menjelaskan dan menafsirkan karya sastra (Hardjana, 1981). Dengan memahami aspek-aspek kejiwaan tokoh utama dalam karya sastra, masyarakat (pembaca) dapat mengetahui perubahan, kontradiksi, dan penyimpangan-penyimpangan lain yang terjadi dalam masyarakat, khususnya dalam kaitannya dengan psike (jiwa). Dalam hal ini, karya sastra (novel) memberikan pemahaman terhadap masyarakat secara tidak langsung.

Berdasarkan pemikiran tersebut, novel Tanah Surga Merah (Nur, 2016) relevan dibahas dengan pendekatan psikologis yang memfokuskan pada karakter tokoh utama. Novel ini menghadirkan tindakan tokoh utama yang berani melawan kelompok tertentu yang menggunakan kekuatan politik untuk melegalkan kekerasan. Novel yang diterbitkan oleh Gramedia Pustaka Utama ini merupakan pemenang unggulan sayembara novel yang diadakan oleh Dewan Kesenian Jakarta tahun 2016.

Masalah utama yang diangkat oleh Arafat Nur adalah tokoh utama laki-laki yang mengalami konflik batin disebabkan oleh peristiwa-peristiwa yang menakutkan. Tokoh utama dalam novel tersebut adalah seorang mantan tentara GAM yang telah menjadi buron dan bersembunyi selama lima tahun di Riau. Ia kembali ke Aceh karena rindu kampung halamannya. Namun, tidak mudah bagi seorang mantan tentara GAM untuk menjalani hidup baru, berkumpul dengan keluarganya, hidup bebas, dan bisa diterima oleh semua pihak, baik pihak penguasa (pemerintah) maupun masyarakat setempat. Ancaman pembunuhan dari mantan tentara GAM yang telah menjadi penguasa, selalu menghantuinya sehingga membuat dirinya merasa cemas dan waswas. Walau demikian, ia tetap berani melangkah dan berjuang meraih asa.

Penelitian terhadap Novel Tanah Surga Merah telah dilakukan antara lain oleh Cut Dian Rahmawati (2017), Lulu Farhatul Ummah (2018) (2018), Muhamad Suhar, Yusak Hudiyono, dan Irma Surayya Hanum (2019), dan Rikki Alzuardi, Antonius Totok Priyadi, dan Ahmad Rabiaul Muzammil (2019). Cut Dian Rahmawati dalam penelitiannya mengungkapkan bahwa dalam novel Tanah Surga Merah terdapat aspek sosial yang meliputi kejahatan sosial, kemiskinan, dan pendidikan. Kejahatan sosial mengandung aspek kejahatan dari segi moral, agama, dan politik. Aspekaspek sosial ini relevan dengan pembelajaran sastra di kelas XII semester genap (Rahmawati, 2017). Lulu Farhatul Ummah dalam penelitiannya mengungkapkan bahwa novel Tanah Surga Merah merupakan potret Aceh pascaperjanjian damai yakni potret sosial dan potret politik. Potret sosial meliputi perekonomian, perubahan sosial, dan nilai-nilai sosial masyarakat. Kehidupan sosial ekonomi maupun politik membawa kepada wujud pertikaian semakin terpuruk lantaran tidak adanya perimbangan keuangan antara pemerintahan pusat dan daerah. Nilainilai sosial dan politik ini dapat 
dijadikan sebagai bahan pembalajaran sastra di sekolah SMA (Ummah, 2018). Muhamad Suhar, Yusak Hudiyono, dan Irma Surayya Hanum meneliti dengan perpektif hegemoni Gramsci. Diungkapkan bahwa dalam novel Tanah Surga Merah ditemukan dua wilayah hegemoni, yakni masyarakat sipil dan masyarakat politik, kemudian dari dua wilayah tersebut ditemukan bentukbentuk hegemoni yang berlangsung. Bentuk hegemoni yang terdapat pada masyarakat sipil adalah dipengaruhi melalui kampanye berkedok agama, patuh terhadap penguasa, takut terhadap ancaman penguasa, dan timbulnya gerakan perlawanan untuk menjatuhkan penguasa. Bentuk hegemoni yang terdapat pada masyarakat politik adalah menyingkirkan penentang, memanipulasi pikiran masyarakat, memengaruhi kepercayaan masyarakat, dan berkuasa secara penuh di wilayahnya (Muhammad, Hudiyono, \& Hanum, 2019). Penelitian Rikki Alzuardi, Antonius Totok Priyadi, dan Ahmad Rabiaul Muzammil mengungkapkan bahwa tokoh utama dalam novel Tanah Surga Merah memiliki konflik internal dan konflik eksternal. Konflik internal meliputi rasa bingung, sedih, tidak pasti, takut, senang, curiga, sakit hati, malu, dan kecewa. Sedangkan konflik eksternal meliputi konflik fisik dan konflik sosial (Alzuardi, Priyadi, \& Muzammil, 2019).

Perbedaan penelitian ini dengan penelitian sebelumnya, yaitu penelitian yang dilakukan oleh Cut Dian Rahmawati (2017) dan Lulu Farhatul Ummah (2018). Kedua penelitian tersebut menyoroti aspek-aspek sosial, ekonomi, dan politik dalam novel yang dapat digunakan sebagai bahan pembelajaran di SMA dan SMK. Penelitian yang dilakukan oleh Muhamad Suhar, Yusak Hudiyono, dan Irma Surayya Hanum (2019) juga memiliki perbedaan dengan penelitian ini. Dalam penelitiannya, diungkapkan bentuk-bentuk hegemoni, yakni masyarakat sipil dan masyarakat politik. Penelitian ini lebih berfokus pada kepribadian tokoh utama berupa personifikasi atau gambaran diri berupa kepuasan dan kecemasan.

Penelitian ini memiliki kesamaan dengan penelitian sebelumnya, yaitu penelitian yang dilakukan oleh Rikki Alzuardi, Antonius Totok Priyadi, dan Ahmad Rabiaul Muzammil (2019) yang menyoroti aspek psikologis tokoh utama. Namun, terdapat perbedaan dalam hal mengulik konflik internal tokoh utama. Penelitian ini lebih mendalam dengan menggunakan konsep teori psikiatri interpersonal oleh Harry Stack Sullivan, sedangkan penelitian sebelumnya hanya mendekati dengan psikologi sastra secara umum. Dengan demikian, penelitian kepribadian tokoh utama novel Tanah Surga Merah yang berfokus pada aspek personifikasi perlu dilakukan. Penelitian ini diharapkan mampu menambah pengetahun tentang analisis psikoanalisis yang lebih komprehensif.

Masalah yang diungkap dalam penelitian ini adalah bagaimanakah kepribadian tokoh utama dalam novel Tanah Surga Merah? Penelitian ini ini bertujuan untuk mendeskripsikan kepribadian tokoh utama dalam novel Tanah Surga Merah.

\section{LANDASAN TEORI}

Harry Stack Sullivan adalah pencipta segi pandangan baru yang terkenal dengan nama interpersonal theory of psychiatry (Hall \& Lindzey, 1993). Ajaran pokok teori ini dalam hubungannya dengan teori kepribadian ialah bahwa kepribadian adalah pola yang relatif menetap dari situasi-situasi antarpribadi yang berulang yang menjadi 
ciri kehidupan manusia. Kepribadian merupakan suatu entitas yang tidak dapat dipisahkan dari situasi-situasi antarpribadi, dan tingkah laku antarpribadi merupakan satu-satunya segi yang dapat diamati sebagai kepribadian. Oleh karena itu, Sullivan berpendapat bahwa yang menjadi unit penelitian adalah situasi antarpribadi. Organisasi kepribadian terdiri dari peristiwa-peristiwa antarpribadi, bukan peristiwa-peristiwa intrapsikis. Salah satu konsep mengenai struktur kepribadian yang diungkapkan Sullivan adalah personifikasi. Personifikasi dijelaskan sebagai suatu gambaran (image) yang dimiliki individu tentang dirinya sendiri atau orang lain. Personifikasi adalah perasaan, sikap, dan konsepsi kompleks yang timbul karena mengalami kepuasan kebutuhan atau atau kecemasan.

Hubungan interpersonal yang memberi kepuasan cenderung membangkitkan image positif, sebaliknya yang melibatkan kecemasan membangkitkan image negatif. Kedua gambaran (image) itu mula-mula terpisah, namun kemudian muncul image lainnya tentang objek yang merupakan gabungan dari kedua image itu dan membentuk image yang kompleks dan realistik tentang objek tersebut (Alwisol, 2004).

Dalam perkembangan kepribadian, manusia ketika bayi mulai membedakan dirinya dengan lingkungannya, mulai terbentuk personifikasi diri dan orang lain. Gambaran mengenai diri sendiri yang berkembang adalah saya baik (good-me) yang dikembangkan dari pengalaman dihadiahi, dimulai dari hadiah kepuasan makan. Personifikasi saya buruk (bad-me) dikembangkan dari pengalaman kecemasan akibat perlakuan atau pengalaman ditolak atau dihukum. Keduanya, good me dan bad me bergabung ke dalam gambaran diri.
Personifikasi yang ketiga adalah adalah bukan saya (not me). Personifikasi ini dikembangkan dari dari pengalaman kecemasan yang sangat berat, seperti kekerasan fisik atau mental karena pengalaman itu sangat menakutkan. Semua mengenai diri yang berhubungan dengan pengalaman itu dipisahkan dari keseluruhan kepribadian atau dikeluarkan dari kesadaran. Personifikasi "saya seorang yang baik" disebabkan oleh pengalaman-pengalaman antarpribadi yang menyenangkan, sedangkan personifikasi "saya seorang yang buruk" disebabkan oleh situasisituasi yang membangkitkan kecemasan. Kecemasan yang dimaksud Sullivan tersebut adalah penghayatan tegangan akibat adanya ancaman-ancaman nyata atau luarnya dibayangkan terhadap keamanan seseorang (Hal936).

Konsep teori tersebut memiliki relevansi dengan persoalan (batin) yang dialami oleh tokoh Murad. Laki-laki mantan tenatara GAM itu mengalami siksaan fisik dan batin ketika akan kembali ke kampung halamannya di Aceh. Banyak tuduhan kejahatan yang ditujukan kepada dirinya, baik dari pemerintahan (anggota dewan dan kepolisian), sehingga ia sering mendapati siksaan fisik yang batin.

\section{METODE PENELITIAN}

Penelitian ini menggunakan metode deskriptif kualitatif. Data yang diperoleh dianalisis secara deskriptif dengan penjelasan sesuai teori yang digunakan. Novel Tanah Surga Merah (2016) karya Arafat Nur adalah bahan yang dikaji dalam tulisan ini. Pembahasan berfokus pada karakter tokoh utama, yakni seorang laki-laki, mantan tentara Gerakan Aceh Merdeka (GAM) yang memiliki perkembagan kepribadian dinamis. Tujuan penelitian ini adalah mengungkapan kepribadian 
tokoh utama, Murad. Meliputi personifikasi (personification) positif, personifikasi negatif, dan personifikasi yang kompleks dan realistik. Metode yang digunakan adalah metode deskriptif analisis dengan pendekatan psikoanalisis. Dalam penelitian ini, penulis menghubungkan isi cerita dan cara penceritaan dengan prinsip-prinsip yang ada dalam konsep teori psikiatri interpersonal oleh Harry Stack Sullivan.

Jika dikaitkan dengan teks (sastra), yakni Novel Tanah Surga Merah, konsep teori tersebut dapat digunakan untuk mengungkapkan kepribadian tokoh utama yaitu timbulnya kecemasan, kepuasan, dan berpikir realistik. Keterkaitan antara psiko-sosial dengan novel tersebut adalah bahwa konflikkonflik, dan kecemasan-kecemasan muncul sebagai efek atau dampak dari personifikasi yang dibangun dari dari luar dirinya yaitu berdasarkan peristiwaperistiwa antarpribadi dan pengalamanpengalaman dari tingkah laku/sikap orang lain.

\section{PEMBAHASAN}

\section{Identitas Tokoh Utama Novel Tanah Surga Merah}

Novel Tanah Surga Merah menampilkan tokoh utama laki-laki bernama Murad. Ia adalah mantan pejuang (tertara) Gerakan Aceh Merdeka (GAM) yang melarikan diri dan bersembunyi di Riau selama lima tahun karena menjadi buron polisi dan orangorang Partai Merah. Sebelum menjadi buronan, Murad adalah pejuang kemerdekaan bersama tiga ratus lebih pejuang lain yang dipuja-puji, ditakuti, dan juga disegani banyak orang.

Keputusannya untuk menjadi tentara GAM dilatarbelakangi ketidaksukaannya terhadap tentara Indonesia yang kasar dan kejam terhadap penduduk setempat. Di usia muda, ia lebih memilih menjadi pejuang daripada melanjukan sekolahnya. Tidak seperti sahabatnya yang beranama Abduh yang melilih melanjutkan sekolah hingga menjadi guru negeri. Perjuangannya membela kaum lemah begitu kuat sehingga ia berani mengambil risiko yang berat.

Ketika seorang gadis akan diperkosa oleh seorang mantan tentara GAM yang telah menjabat sebagai anggota dewan dan bergabung dengan Partai Merah, Murad membela gadis itu. Ia memuntahkan peluru ke anggota dewan, anggota Partai Merah, tersebut hingga tewas. Peristiwa inilah yang memicu polisi dan orang-orang Partai Merah memburunya karena dianggap sebagai pembunuh yang kejam. Murad juga dianggap sebagai seorang pengkhianat karena dianggap memiliki peran penting di balik kerusuhan yang menentang Partai Merah. Bahkan lahirnya Partai Jingga adalah gagasan Murad. Ia dianggap merancang Partai Jingga untuk memecah Partai Merah sehingga partai penguasa itu mulai goyah. Murad juga dianggap sebagai penampung ganja yang dikirim ke luar Aceh. Untuk menghindari penangkapan dirinya, ia melarikan diri ke Riau.

Setelah lima tahun hidup dalam pelarian, Murad kembali ke kampung halamannya di Baloh, Aceh. Di sini, Murad tetap diincar oleh Partai Merah dan polisi. Ancaman pembunuhan terhadap dirinya datang silih berganti. Bahkan kekejaman berupa pengeroyokan dan penyiksaan ia alami.

Karena di kampung halamannya, Baloh, hidupnya terancam, Murad kemudian melarikan diri dengan dibantu Dahli ke Kampung Klekklok. Dahli mengantar Murad ke Kampung Klekklok atas perintah Imran untuk menyelamatkan diri. Di kampung inilah Murad mendapat keajaiban-keajaiban 
yang tidak terduga. Ia memperoleh pengalaman-pengalaman yang menegangkan, yang mendorong dirinya berpikir realistis. Karena ada gerombolan orang Partai Merah menuju Kampung Klekklok yang akan menangkapnya, ia diajak Jemala pergi jauh dari kampung Klekklok menuju puncak bukit dengan hamparan tumbuhan ganja. Di sinilah, ia bersama Jemala memperoleh kebebasan hidup.

\section{Kepribadian Tokoh Utama dalam Novel Tanah Surga Merah}

Kepribadian tokoh utama meliputi personifikasi positif, personifikasi negatif, dan personifikasi yang kompleks dan realistik. Sensasi berupa perasaan, sikap, pikiran dan konsepsi kompleks tersebut timbul karena mengalami kepuasan kebutuhan atau kecemasan. Hubungan interpersonal yang memberi kepuasan cenderung membangkitkan image positif, sebaliknya yang melibatkan kecemasan membangkitkan image negatif. Kedua gambaran (image) itu mula-mula terpisah, tetapi kemudian muncul image lainnya tentang objek yang merupakan gabungan dari kedua image itu dan membentuk image yang kompleks dan realistik tentang objek tersebut (Placeholder1).

\section{Personifikasi Positif Tokoh Utama}

Dalam Novel Tanah Surga Merah, tokoh utama, Murad, mula-mula adalah seorang pemuda remaja yang memiliki kepedulian terhadap nilai-nilai kemanusiaan. Pada situasi yang penuh gejolak antara masyarakat Aceh dengan pemerintah, ia melihat adanya ketidakadilan dan kesewenangwenangan yang dirasakan masyarakat. Ia pun tergerak hatinya untuk andil dalam memperjuangkan kebebasan bagi masyarakat Aceh. Ia kemudian memutuskan untuk menjadi pejuang (tentara) Gerakan Aceh Merdeka (GAM). Ia merasa tidak tahan melihat tentara Indonesia yang kasar dan kejam terhadap penduduk setempat, sebagaimana tergambar pada kutipan berikut.

... Aku memutuskan keluar sekolah dan bergabung dengan pejuang atas kemauanku sendiri karena tidak tahan dengan sikap dan kelakuan tentara yang begitu kasar dan kejam; mereka kerap membunuh, menculik, menjarah, dan memukuli orangorang-seakan hanya itulah tugas utama para tentara yang dianjurkan Negara (Nur, 2016).

Dari kutipan tersebut, tergambar bahwa Murad adalah seorang pemuda yang peka terhadap situasi sosial politik yang merugikan masyarakat setempat. Ia rela keluar dari sekolah demi berjuang membela kebenaran dan melawan kekejaman penguasa. Sikap Murad sebagai seorang pemuda menggambarkan dirinya memiliki prinsip yang positif.

Murad pun menjadi tentara gerilya, pejuang kemerdekaan yang dipuja-puji, ditakuti, dan juga disegani banyak orang. Ia menjabat sebagai Wakil Panglima Sagoe merangkap juru bicara. Selama menjadi gerilyawan, Murad tak pernah menembak mati musuhnya. Ia dan kawan-kawannya kerap menembaki lawan untuk menakut-nakuti tentara baru yang terlihat masih kanak-kanak.

Keputusan Murad untuk menjadi pejuang untuk membela kebenaran, menggambarkan dirinya sebagai pribadi yang memiliki pemikiran, perasaan, dan sikap yang positif. Image positf itu didukung dengan jabatan yang ia sandang saat menjadi gerilyawan, sebagai Wakil Panglima Sagoe merangkap juru bicara. Demikian juga dengan sikapnya yang tidak pernah 
menembak tentara (Indonesia) yang menjadi musuhnya selama ia menjadi pejuang Gerakan Aceh Merdeka, menujukkan bahwa ia adalah pribadi yang humanis. Semua perilaku itu pantas mendapat pujian dari masyarakat.

Setelah kesepakatan damai dimulai, dibentuklah partai-partai politik lokal Aceh. Beberapa elit GAM dan mantan pejuang mendirikan partai dan mereka terjun langsung ke dunia politik praktis. Salah satu partai yang paling berkuasa saat itu adalah Partai Merah. Melalui Partai Merah, partai lokal yang selalu memenangkan pemilu, mereka menduduki tempat-tempat penting terhormat di pemerintahan, baik sebagai kepala pemerintah, pejabat, maupun anggota dewan. Orang-orang Partai Merah memiliki sikap yang menjengkelkan, seolah Aceh sudah merdeka dan berada dalam genggamannya dengan dilindungi rahmat Tuhan Yang Kuasa. Padahal mereka begitu takut kepada pada tentara dan polisi. Mereka hanya berani bersikeras dan menekan kaum sendiri. Dengan alasan itu, Murad beberapa kali sempat menulis artikel di surat kabar lokal dengan nama samaran, yang semuanya berupa gagasan pentingnya mendirikan Partai Jingga. Partai Jingga kemudian benar-benar berdiri untuk memecah pengikut Partai Merah.

Perilaku orang-orang Partai Merah tidak hanya menjengkelkan, tetapi juga berlaku biadab terhadap gadis-gadis remaja. Ia berani mengganggu, bahkan memerkosanya. Perilaku seperti inilah yang membuat Murad mendidih otaknya dan bertindak nekat seperti pada kutipan berikut.

Aku yang telah lama menahan diri mulai membawa lagi sepucuk pistol tua lama buatan Belgia yang tidak ikut keserahkan saat terjadi kesepakatan damai dengan pemerintah dulu. Senjata kuselipkan di pinggang untuk berjaga-jaga, dan sungguh tidak menyangka aku bakal mendapati lelaki yang hendak memerkosa Fitri begitu aku tiba di rumahnya menjelang Isya.

...

Begitu mendengar jeritan dari dalam, darah jantungku seketika menyala. Aku mendobrak pintu dan langsung memuntahkan tembakan ke tubuh Jumadil yang menatapku ketakutansampai lima peluru yang tersisa habis keluar, semuanya mengenai sasaran. Sebutir segaja kuarahkan ke kelaminnya sehingga alat penting itu hancur tak berbentuk (Nur, 2016).

Dari kutipan tersebut, dapat diketahui bahwa Murad sangat melindungi kaum lemah seperti gadis belia dari kekejaman orang-orang dari kelompok penguasa. Oleh karena itu, ketika ia melihat seorang laki-laki yang hendak memerkosa gadis belia, spontan kemarahannya memuncak kemudian menembak lelaki itu demi melindungi si gadis. Ia begitu marah dan tidak tahan melihat perilaku kejam orang-orang dari kelompok penguasa terhadap masyarakat desa yang lemah terutama gadis belia yang seharusnya dilindungi dan dijaga kehormatannya.

Dari berbagai peristiwa yang dilakukan Murad, menyebabkan ia harus melarikan diri dan bersembunyi di tempat asing. Ia diburu polisi dan orangorang Partai Merah karena dianggap sebagai pembunuh dan pengkhianat. Jumadil yang ditembak Murad, adalah anggota dewan, tokoh penting Partai Merah. Oleh karena itu, Murad dianggap sebagai seorang pengkhianat yang membahayakan, khususnya orang-orang Partai Merah. Murad menjadi buron polisi dan orang-orang Partai Merah. 


\section{Personifikasi Negatif Tokoh Utama}

Dalam Novel Tanah Surga Merah, tokoh Murad yang melarikan diri ke Riau, lima tahun kemudian kembali ke Aceh karena rindu kampung halamannya, yaitu Baloh. Namun, tak mudah untuk tinggal kembali di kampung halamannya karena ita telah menjadi buron yang harus ditangkap dan dibunuh. Di Baloh, ia menemukan banyak persoalan yang membuat dirinya terkekang, tidak bisa bergerak. Sebagai pelarian yang dituduh menjadi pembunuh keji, membuatnya tidak merasa tenang. Banyak sindiran, ancaman, dan serangan dari masyarakat. Di sepanjang perjalanan pulang ke kampung halamannya, ia milihat orangorang Partai Merah yang angkuh dan congkak. Biasanya, mereka memperbincangkan masalah seputar proyek, jabatan, dan perempuan meskipun sudah menjadi anggota dan pejabat terpandang.

Dalam perjalanan pulang ke kampung halamannya, ada beberapa orang yang mengenali Murad sehigga terjadi pengeroyokan. Ia babak belur. Perhatikan kutipan berikut.

Tak lama kemudian, yang lain berhasil mencapaiku, ada yang meninju mukaku, menendang kakiku, dan memukuliku di mana saja yang bisa mereka pukul. Aku mengaduh minta ampun, tetapi mereka tak menghiraukannya; menyumpahiku sebagai pembunuh, pengkhianat, dan entah apa lagi.

Baru saat itu aku menyadari, bahwa di antara mereka ada Saifud, yang merupakan kaki tangan Suardin sang wali kota ... (Nur, 2016).

Kutipan tersebut menggambarkan bahwa Murad masih diburu terutama oleh penguasa, seperti wali kota. Mereka tak ragu untuk bertindak kejam.
Menghadapi persoalan seperti itu, Murad merasa cemas. Ia diliputi rasa putus asa, sedih, dan kecewa yang teramat dalam sebagaimana terefleksi pada kutipan berikut.

Kusadari, sejak aku menjadi pelarian imanku semakin tipis. Aku senantiasa diliputi rasa putus asa, sedih, dan kecewa yang teramat dalam terhadap dunia ini. Kecintaanku yang begitu besar terhadap tanah kelahiran justru amat mengecewakan. Namun, aku tetap mencintai dengan seluruh jiwa raga dan napasku. Di sinilah ketenangan, hidup, dan matiku. Aku tidak bisa hidup di tempat lain, bagaimanapun makmur dan indahnya negeri itu (Nur, 2016).

Kutipan tersebut secara jelas menggambarkan dirinya yang kuat namun mengalami kecemasan. Kecintaannya yang amat besar terhadap tanah kelahirannya, justru membuat dirinya amat kecewa. Ia merasa ditolak oleh lingkungannya sendiri. Akibat dari perlakuan atau pengalaman ditolak atau dihukum, Murad mengalami kecemasan. Kekecewaan Murad juga tergambar pada kutipan berikut.

Sebelum runtutan peristiwa yang menyebabkan aku harus melarikan diri dan bersembunyi di tempat yang asing, tidak lama setelah kesepakatan damai dimulai, aku adalah pejuang kemerdekaan bersama tiga ratus lebih pejuang lain yang dipuja-puji, ditakuti, dan juga disegani banyak orang. Sekarang telah berbalik tajam, aku bukan pahlawan melainkan penjahat buronan yang diintai polisi dan diburu orang-orang Partai Merah yang menaruh dendam kesumat (Nur, 2016).

Kutipan tersebut menggambarkan kekecewaan yang amat dalam dalam diri 
Murad. Perjuangannya saat menjadi tentara GAM untuk membebaskan masyarakat dari perilaku sewenangwenang tentara Indonesia seolah tidak ada artinya. Ia hanya dianggap sebagai pengkhianat dan pembunuh yang harus dilenyapkan tanpa melihat penyebabnya. Keadaan yang demikian menjadikan dirinya amat kecewa.

Segala persoalan yang mengelilinginya, menjadikan hidupnya terbelenggu oleh ancaman yang membuat dirinya harus super hati-hati dalam bergerak. Untuk mengurangi kecemasannya, Murad mencoba menemui sahabatnya, Abduh, seorang guru sejarah yang sering menulis novel dan bermain teater. Murad pun hadir melihat pentas drama yang disutradari Abduh. Drama itu menyampaikan pesan bahwa masyarakat harus menyukai buku dan membaca. Kehadiran Murad terendus oleh Partai Merah sehingga ia harus menerima pengeroyokan yang mengakibatkan patah tulang kaki. Hidupnya pun makin terancam, baik oleh orang-orang Partai Merah maupun polisi.

Semua pengalaman hidup yang menyakitkan itu menimbulkan kecemasan yang cenderung memberi image negatif. Ia menjadi buronan polisi dan Partai Merah. Di samping dituduh berkhianat terhadap pemerintah, menjadi pembunuh, dan ingin menumbangkan Partai Merah dengan cara mendirikan Partai Jingga, ia juga dituduh sebagai penjual ganja. Tuduhan-tuduhan itu tergambar dalam dialog antara Abduh dengan Mukhtar pada kutipan berikut.

\footnotetext{
"Menurutmu, kenapa mereka begitu marah padaku?"

"Bukankah kau yang lebih tahu?" tanyanya berbali.

"Sama sekali aku tak mengerti."

"Bukan masalah penembakan

Jumadil saja yang membuat mereka
}

begitu murka, tetapi dianggap punya peranan penting di balik kerusuhan yang menentang Partai Merah. Bahkan mereka yakin lahirnya Partai Jingga adalah gagasanmu. Kaulah yang merancang perpecahan di tubuh partai yang sedang berkuasa itu sehingga sekarang mulai goyah". "Bagaimana mereka bisa berpikir begitu?"

"Kau ini bukan hanya militan, tapi juga pemikir. Mereka tahu kau menulis artikel di koran dengan nama samaran."

"Aku dengar kau juga penampung ganja-ganja yang dikirim ke luar Aceh. Itu pula sebabnya polisi sibuk mencarimu lima tahun lalu, saat sejumlah koran gencar memberitakanmu ..." (Nur, 2016).

Kutipan tersebut menggambarkan betapa berat ancaman polisi dan orangorang Partai Merah terhadap dirinya. Meski ia tak memiliki harta benda, ia akan tetap tinggal di Aceh. Ia tetap mencoba untuk meraih asa, melindungi dan mencerdaskan masyarakat Aceh dengan sekuat tenaga dan pikiran meski fisiknya lemah. Ia juga sangat mencintai tanah kelahiran beserta masyarakatnya yang mengalami ketidakadilan. Ia pun ingin tinggal dan hidup tenang meski sangat membenci para pejabat pemerintahnya. Ia tidak mau berurusan dengan siapa pun. Ia sangat membenci Partai Merah juga partai-partai nasional yang beranggotakan orang-orang berjanggut panjang yang sok taat agama dan hatinya tak kurang busuk dibandingkan anggota partai lainnya, bahkan ada di antara mereka yang banyak yang lebih busuk. Ia menganggap orang-orang yang duduk di pemerintahan itu laknat yang dikirimkan Tuhan dari neraka. Oleh karena itu, 
sebisa mungkin ia menghindari mereka sejauh-jauhnya.

Berbagai ancaman terhadap keamanan diri Murad mengantarkan dirinya dalam kecemasan yang dahsyat. Ia mengalami tegangan akibat dari adanya ancaman, baik yang nyata atau dibayangkan. Pengalaman hidup yang buruk disebabkan oleh situasi-situasi yang membangkitkan kecemasan itu menunjukkan gambaran diri (personifikasi) yang negatif .

\section{Personifikasi yang Kompleks dan Realistik Tokoh Utama}

Gambaran (image) yang kompleks dan realistik menurut Sullivan merupakan objek bentukan baru dari gabungan gambaran (image)—saya baik (good me) dan saya buruk (bad me) yang pada awalnya terpisah. Personifikasi ini dikembangkan dari pengalaman kecemasan yang sangat, seperti kekerasan fisik atau mental. Karena pengalaman itu sangat menakutkan, semua yang mengenai diri yang berhubungan dengan pengalaman itu dipisahkan dari keseluruhan kepribadian atau dikeluarkan dari kesadaran (Alwisol, 2004).

Berkaitan dengan tokoh Murad yang memiliki image negatif dari pengalaman hidupnya yang penuh dengan konflik batin (kecemasan), personifikasi kepuasan muncul atau dibangun dari usahanya atau perjuangannya melindungi diri dari serangan orang-orang Partai Merah dan polisi agar ia bisa berbuat baik kepada orang lain atau masyakat yang membutuhkannya.

Tanah kelahirannya, Baloh, yang ia cintai tidak bisa memberi rasa aman dan nyaman. Hidupnya selalu terancam oleh serangan orang-orang Partai Merah dan polisi. Teman-teman dekatnya pun tidak bisa memberi jaminan keamanan kepadanya. Ketika Murad berada di rumah temannya yang bernama Usman, tiba-tiba diserbu oleh gerombolan Partai Merah. Oleh istri Usman, Murad disuruh bersembunyi di dalam tumpukan jerami kering. Sambil menahan rasa sakit di kaki dan sesak napas oleh tumpukan jerami, Murad merasa panik karena gerombolan itu sempat menusuk-nusuk tumpukan jerami tempat persembunyiannya. Murad sudah benarbenar merasa terdesak oleh serangan, jalan satu-satunya ia harus mengungsi jauh masuk ke wilayah terpencil di tengah hutan yang sulit dijangkau. Keesok harinya atas amanah dari Imran, sahabatnya, Murad harus disembunyikan demi melindungi dari serbuan. Murad diminta menyamar menjadi seorang teungku. Ia pun diganti namanya menjadi Teungku Ghafar Sabi dan berpakaian jubah putih. Dengan kondisi kaki yang pincang, ia dilarikan oleh temannya yang bernama Dahli ke sebuah kampung terpencil di tengan hutan. Kampung itu bernama Klekklok, yang ia sebut sebagai Kampung Jin karena di kampung ini masyarakatnya berperilaku sangat aneh. Ia dibawa (diboncengkan) oleh Dahli menggunakan kereta ke pelosok hutan yang jauh dari Baloh. Sebelum tiba di kampung Klekklok, Murad dan Dahli harus menempuh jalan yang sulit. Dahli menghentikan keretanya di kampung Pungget untuk mengisi bahan bakar. Dari kampung ini, masih setengah perjalanan menuju kampung Klekklok. Setelah melewati hutan rimba dan naik turun gunung dan memakan waktu semalam suntuk, sampailah di sebuah kampung bernama Klekklok. Dahli memperkenalkan Murad sebagai Teungku yang akan melindungi mereka sebagaiama tergambar pada kutipan-kutipan berikut.

"Saudara-saudara! Ini adalah Teungku Ghafar Sabi, pandai agama 
yang dikirim pemerintah kemari!" teriak Dahli pada sekalian orang yang membuat perutku mual. "Kalian perlu belajar agama dan semoga Allah melindungi kalian semua dari bencana alam dan petaka dunia!" (Nur, 2016).

Kutipan tersebut secara jelas disebutkan oleh Dahli bahwa Murad (Teungku Ghafar Sabi) adalah seorang teungku yang dikirim pemeritah untuk menyelamatkan kampung dari bencana. Ia akan mengajari agama kepada warga Klekklok. Oleh karena Itu, penduduk desa yang memang membutuhkan pelindung langsung bereaksi, menyambut gembira kedatangan Murad. Penduduk desa pun langsung bertindak sesuai pemikiran mereka bahwa seorang teungku harus diperlakukan dengan istimewa sebagaimana tergambar pada kutipan berikut.

"Berikan tangan Teungku yang suci itu untuk kami cium," kata perempuan tua itu mengiba.

"Suci apanya!" ketusku menatapnya

tajam. "Tanganku tidak suci, dan

tidak ada seorang pun di kampung ini yang perlu mencium tanganku!"

Terdengar sejumlah perempuan berbisik-bisik dalam kerumunan yang semakin ramai mengelilingiku.

"Aneh, kenapa dia menolak tangannya dicium?"

"Ah, kamu ini," sela yang lain menuding. "Tangannya terlalu suci untuk tubuh kita yang kotor berlumur dosa!" (Nur, 2016).

Murad begitu terkejut ketika melihat penduduk kampung yang mengerubunginya. Mereka semua berusaha mencium tangan Muarad, lebih-lebih ketika ia ditinggal sendirian oleh Dahli, rasanya ia ingin menemui Imran dan menempeleng mukanya karena pelarian dirinya itu atas ide Imran, sahabatnya. Ia merasa jengkel diperlakukan sangat istimewa oleh warga kampung. Warga kampung menganggap dirinya sebagai orang suci yang akan mengajari agama dan menyelamatkan dari bencana.

Perilaku aneh penduduk desa Klekklok tersebut justru membuat Murad sangat kesal. Ia tidak suka diperlakukan berlebihan oleh penduduk. Bagi Murad, status sebagai Teungku Ghafar Sabi adalah sangat menjengkelkan. Gelar teungku itu sebenarnya palsu, merupakan perintah (ide) temannya yang bernama Imran untuk melindungi diri dari serangan partai Merah. Ketika ia dibawa lari (berlindung) oleh Dahli ke desa Klekklok, ia benar-benar harus berperan sebagai seorang teungku yang pandai mengaji dan menjadi penutan atau tempat menyelesaikan segala persoalan masyarakat desa. Perasaan jengkel Murad itu sudah muncul sejak awal setiba di desa Klekklok yang sangat sepi dan terisolir. Hal itu tergambar pada kutipan berikut.

Setiba di kampung Klekklok, Murad benar-benar merasa dibuang ke dalam perangkap yang membuatnya tidak bisa berkutik. Seandainya terjadi pengepungan, ia tidak bisa lari ke mana-mana.

Tiba-tiba saja aku menjadi orang yang sangat pasrah dan imanku pun terasa meingkat. Entah pengaruh pakaian yang kupakai ini, terasa sangat ganjil, dan seolah-olah aku tetap saja seorang badut (Nur, 2016).

Kejengkelan hati Murad bertambah ketika kelakuan penduduk terhadap dirinya semakin menggila. Mereka kemudian berlomba-lomba saling memperkenalkan diri dan menawarkan rumahnya agar ditempati oleh Murad. Murad memilih tinggal di 
rumah Buleun bersama seorang anak laki-lakinya bernama Jamil yang siap menemani dan melayani. Di sini, banyak peristiwa yang secara tiba-tiba membuat Murad terheran-heran. Semisal, ketika Buleun melihat Murad berlalu di hadapannya, ia langsung menangkap tangannya dan menarik-nariknya seperti anak kecil. Betapa terkejutnya Murad diperlakukan seperti itu. Mungkin dia mengira Murad akan segera pergi dari kampung.

Penduduk desa semakin hari semakin mengagungkan Murad sebagai Teungku Ghafar Sabi. Hal ini terjadi karena mereka memang mendambakan seseorang yang bisa melindungi dan membimbing mereka ke jalan yang baik, seperti mengajari agama, dan menyelesaikan segala persoalan seharihari yang dihadapi mereka. Tingkah laku penduduk desa yang semakin menjadijadi itu tergambar pada kutipan berikut.

"Maafkan kelancanganku, Teungku. Kami perlu menghormati orang yang akan membawa berkah dan rahmat bagi kampung kami yang kerap ditimpa bencana. Teungkulah penyelamat kami!" (Nur, 2016).

Bagi Murad, persoalan-persoalan tersebut bukan tanggung jawabnya. Murad sendiri datang ke desa tersebut bertujuan berlindung dari serangan Partai Merah. Di samping itu, Murad merasa bukan seorang teungku yang pandai mengajarai agama. Hal itu tergambar pada kutipan berikut.

Persekongkolan Imran dan Dahli ini tidak lucu. Betapa teganya mereka mengirimkan aku kemari sebagai seorang teungku palsu hanya untuk menipu orang-orang kampung terbelakang ini. Tidakkah mereka berpikir bahwa aku harus mengkhianati diri sendiri dengan berpura-pura menjadi pandai agama yang disanjung-sanjung? Lalu bagaimana nanti bila aku disuruh mereka mengajar mengaji? Tidakkah mereka tahu, aku sendiri tidak terlalu pandai membaca Alquran?! (Nur, 2016).

Kutipan tersebut dengan jelas menggambarkan konflik dalam diri Murad mengenai pengkhiatan atas dirinya sendiri yang harus berpura-pura menjadi orang mulia di depan penduduk desa yang mengagung dirinya sebagai ahli agama. Sementara dirinya dengan sadar bahwa ia kurang memiliki kemampuan dalam ilmu agama.

Dari rasa ragu tentang kemampuan dirinya dan pengkhianatan terhadap dirinya sendiri untuk menghadapi penduduk desa, kemudian berkembang rasa jengkel terhadap penduduk desa yang bersikap berlebihan terhadap dirinya. Hal itu disebabkan batin Murad yang masih bergejolak, ditambah lagi dengan peristiwa-peristiwa yang tidak disukainya, seperti tergambar pada kutipan berikut.

Saat aku terheran-heran dalam kebingungan yang tak menentu, malah Ampon meraih dan mencium tanganku! Aku terkejut bukan kepalang, dan cepat-cepat menariknya.

"Ya ampun, apa yang kaulakukan?" bentakku pada lelaki yang tiba-tiba bertingkah seperti anak kecil ini.

"Maafkan kelancanganku, Teungku. Kami perlu menghormati orang yang akan membawa berkah dan rahmat bagi kampung kami yang kerap ditimpa bencana. Teungkulah penyelamat kami!" (Nur, 2016).

Dalam kondisi jengkel dan bingung menghadapi penduduk desa, datang seorang ibu kepada Murad meminta agar Murad mengobati anak permpuannya bernama Romlah yang 
menderita sakit selama lima tahun. Tentu saja Murad menolak karena merasa tidak bisa mengobati orang sakit. Ibu tersebut terus mengiba dan menganggap Murad adalah seorang teungku yang suci yang mampu mengobati penyakit anaknya. Murad sudah hampir putus asa menghadapi semua perilaku penduduk yang menganggap dirinya orang suci yang harus dihormati dengan cara mencium tangannya. Murad pun kemudian mencoba menerima kenyataan yang ia hadapi.

Murad mencoba memahami dan memenuhi harapan penduduk kampung, menempatkan dirinya sebagai teungku. Faktanya, keajaiban pun terjadi. Ketika Murad menjenguk Romlah yang tidak berdaya dan membisikkan doa agar diberi kesembuhan, ternyata Romlah bangun, padahal sebelumnya ia hanya tergolek di tempat tidur. Dengan peristiwa ini, penduduk desa semakin yakin bahwa Murad-yang dipanggil sebagai Teungku Ghafar Sabi-adalah orang suci.

Peristiwa ajaib yang dialami tokoh Murad tersebut merupakan realitas yang harus diterima. Bisikan doa Murad dan keyakinan sang ibu dan masyarakat desa bahwa Murad adalah orang yang bisa menyembuhkan segala penyakit, membuat Romlah benar-benar sembuh. Hal itu menunjukkan adanya gambaran diri yang kompleks dan realistik.

Sejak Murad dianggap sebagai seorang Teungku Ghafar Sabi yang dipercayai sebagai teungku suci dan mampu melindungi masyarakat desa Klekklok dari bencana, penduduk desa yang berada di pelosok, jauh dari keramaian itu merasa telah mendapat keajaiban-keajaiban. Mereka percaya bahwa Teungku Ghafar Sabi adalah seorang teungku yang dikirim oleh pemerintah untuk melindunginya dengan mengajari agama.
Dari tingkah laku "aneh" penduduk desa terhadap Murad yang terus menerus, dan kenyataan yang menunjukkan keajaiban pada dirinya, menunjukkan bahwa ia memiliki gambaran diri yang kompleks. Ia akhirnya mampu mengubah pola pemikiran Murad. Murad pun kemudian merespon berbagai peristiwa ajaib serta tingkah laku penduduk desa yang "aneh" tersebut sebagai ekspresi rasa hormat penduduk desa terhadap dirinya. Murad kemudian menerima kenyataan bahwa ia harus menempatkan dirinya sebagai seorang teungku seperti yang diharapkan penduduk desa. Setelah lama tertegun, ia kembali berpikir, sudah saatnya ia bertindak untuk memengaruhi mereka, seperti pada kutipan berikut.

"Dengar" kataku lagi dengan pandangan serius. "Semua ini bukan untuk kepentinganku, tapi untuk kalian, untuk kampung ini. Tidak ada pengaruhnya bagiku bila kalian akan memperbaiki atau menelantarkan mesjid itu!" (Nur, 2016).

Murad kemudian membimbing penduduk desa untuk giat beribadah. Penduduk desa secara gotong-royong memperbaiki surau yang sudah rusak dan tidak terpakai. Mereka juga ada yang rela menyumbang material dan uang seadanya demi menghidupkan kembali masjid yang sudah lama mereka tinggalkan. Mereka juga mulai belajar mengaji lagi. Mulai dari sinilah, Murad menyadari bahwa ia harus membantu orang-orang yang membutuhkan bantuan berupa bimbingan menuju kebaikan. Di Desa Klekklok yang terpencil itulah Murad mulai memeroleh kenikmatan hidup, lebih-lebih setelah berkawan dekat dengan Jemala, gadis cantik, cerdas dan pemberani, putri kepala kampung sekaligus keponakan Dahli yang bisa diajak diskusi tentang keberadaan Partai Merah. Faktanya, 
Jemala mengetahui semua maksud kedatangan Murad di Desa Klekklok sejak semula.

Seiring bergulirnya waktu, Murad memperoleh kebahagiaan hidup bersama Jemala, gadis cantik, cerdas. Murad dibawa lari dari desa Klekklok menuju pelosok hutan yang lebih terisolir oleh Jemala. Hal ini dilakukan Jemala karena ia tahu bahwa Partai Merah akan segera tiba di Desa Klekklok untuk menangkap Murad. Murad pun mengikuti gadis cantik yang ia cintai itu ke belantara rimba. Murad pun tidak pernah menyangka jika dalam pelariannya akan bertemu gadis cantik yang cerdas dan pemberani yang selalu melindungi dan bisa menyelamatkan dirinya dari serangan Partai Merah dan polisi. Perhatikan kutipan berikut.

"Aku tidak pernah menyangka dalam hidupku bakal ada seorang gadis belia yang melarikanku begitu jauh ke dalam rimba," ucapku masih kurang percaya dengan kejadian ini.

"Aku juga tidak mengira akan membawa lari buronan polisi yang diburu orang-orang Partai Merah demi menyelamatkan nyawanya," ucapnya menyindir.

Seperti tidak mau beranjak dari tempat ini, kami terus memandang alam sekitar dengan lega. Perlahanlahan aku merasakan tangannya menggenggam tanaganku dan aku menyambut tangannya dengan genggaman yang lebih erat pula ...

Keduanya saling berpegangan tangan, berdiri tegak di dataran agak tinggi dekat sungai, sambil memandangi hamparan luas tanaman ganja yang subur. Sungguh suatu pemandangan yang sangat ganjil di tengah rimba ketika matahari mulai tenggelam dengan langit kesumba! (Nur, 2016).
Kutipan tersebut secara jelas menggambarkan bahwa Murad telah memeroleh kebahagiaan hidup. Setelah melalui jalan panjang dalam pelariannya untuk membebaskan diri dari serbuan Pertai Merah dan polisi, akhirnya ia mendapat kebebasan untuk hidup bebas bersama orang yang ia cintai.

Tokoh Murad pada akhirnya mampu mendorong kesadarannya untuk menerima keajaiban sebagai realitas hidup yang membuat dirinya memperoleh kebebasan sebagaimana ia harapkan sejak awal. Beberapa peristiwa yang membuat dirinya cemas dapat ia lupakan. Kenyataan bahwa penduduk desa Klekklok membutuhkan dirinya sebagai seorang Teungku Ghafar Sabi yang melindungi dan mencerdaskan masyarakat Aceh dengan sekuat tenaga dan pikiran.

\section{PENUTUP}

Berdasarkan hasil pembahasan, dapat ditarik hal penting sebagai benang merah pembahasan ini, yaitu bahwa tokoh laki-laki bernama Murad dalam novel Tanah Surga Merah adalah tokoh yang memiliki karakter kuat. Ia mampu melewati gejolak batinnya yang terombang-ambing antara keputusasaan dan harapan. Ia pun berhasil meraih kebebasan yang membuat dirinya merasa nyaman dalam hidup dan kehidupannya.

Usaha dan perjuangan yang dilakukan Murad untuk memertahankan eksistensi dirinya sebagai seorang mantan penjuang, mampu mengurangi konflik batin dalam dirinya. Tiga hal yang terjadi pada diri tokoh Murad adalah sebagai berikut. Pertama, ia sangat kecewa dengan kebijakan pemerintah yang menganggap mantan tentara GAM harus ditangkap sehingga ia harus hidup dalam pelarian dan menjadi buron polisi karena dianggap berkhianat terhadap pemerintah. Kedua, 
perjuangannya melindungi diri dari serangan orang-orang Partai Merah dan polisi, bertujuan agar ia bisa berbuat baik kepada orang lain atau masyarakat yang membutuhkannya sehingga memperoleh kepuasan batin. Ketiga, untuk memperoleh kebahagiaan hidup, ia berusaha menerima kenyataan bahwa ia telah mengalami keajaiban yang datang dari penduduk desa yang menganggapnya sebagai penyelamat. Ia dianggap sebagai seorang teungku yang dikirim oleh pemerintah untuk melindunginya dengan cara mengajari agama. Dengan demikian, disimpulkan bahwa tokoh utama dalam novel Tanah Surga Merah memiliki kepribadian yang dinamis, yakni personifikasi positif, personifikasi negatif, dan personifikasi yang kompleks dan realistik sehingga mengantarkan dirinya berhasil meraih kebahagiaan hidup.

\section{DAFTAR PUSTAKA}

Alwisol. (2004). Psikologi kepribadian. Malang: UMM Press.

Alzuardi, R., Priyadi, A. T., \& Muzammil, A. R. (2019). "Konflik tokoh utama dalam novel tanah surga merah karya Arafat Nur". Pontianak: FKIP Universitas Tanjungpura.

Darma, B. (1983). Solilokui, Kumpulan esai sastra. Jakarta: Gramedia.

Endraswara, S. (2008). Metode Penelitian psikologi sastra-Teori, langkah dan penerapannya. Yogyakarta: FSB Universitas Negeri Yogyakarta.

Hall, C. S., \& Lindzey, G. (1993). Teoriteori psikodinamik (klinis). Diterjemahkan oleh Yustinus. Yogyakarta: Kanisius.

Hardjana, A. (1981). Kritik sastra Sebuah pengantar. Jakarta: Gramedia.
Hartono, D., \& Rahmanto, B. (1986). Pemandu di dunia sastra. Yogyakarta: Kanisius.

Hudson, W. H. (1961). An introduction to the study of literature. London: George G. Harrap \& Co. Ltd.

Minderop, A. (2011). Psikologi sastra karya sastra. Metode, teori, dan contoh kasus. Jakarta: Yayasan Pustaka Obor Indonesia.

Muhammad, S., Hudiyono, Y., \& Hanum, I. S. (2019). "Analisis novel tanah surga merah karya Arafat Nur: Sebuah kajian hegemoni Gramsci". Ilmu Budaya Vol. 3, No. 4, Oktober 2019, 453--462.

Nur, A. (2016). Tanah surga merah. Jakarta: Gramedia Pustaka Utama.

Rahmawati, C. D. (2017). "Aspek sosial dalam novel tanah surga merah karya Arafat Nur: Tinjauan sosiologi sastra dan implementasinya pada pembelajaran sastra di SMK". Surakarta: Skripsi Fakultas Keguruan dan Ilmu Pendidikan Universitas Muhammadiyah Surakarta.

Ratna, N. K. (2004). Teori, metode, dan teknik Penelitian sastra. Yogyakarta: Pustaka Pelajar.

Ummah, L. F. (2018). "Potret Aceh pascaperjanjian damai dalam novel tanah surga merah karya Arafat Nur dan penerapannya terhadap pembelajaran sastra siswa sekolah menengah atas". Jakarta: Skripsi Fakultas Ilmu Tarbiyah dan Keguruan Universitas Negeri Syarif Hidayatullah Jakarta.

Wellek, R., \& Warren, A. (1989). Teori kesusastraan. Diterjemahkan oleh Melani Budianta. Jakarta: Gramedia. 